\title{
The Changing Role of the Travel Intermediary
}

B Lubbe

Department of Tourism Management, University of Pretoria

\begin{abstract}
This article gives an overview of the changes and developments in the travel industry and the way travel intermediaries like travel agents are responding to them. These changes include the deregulation of airlines and the advent of global distribution systems, the pressure from airlines for lower distribution costs, rapid and fundamental changes in technology and consumer preferences. The responses by travel agents include rapid integration and consolidation within the industry, the use of technology to streamline operations and expand market reach, and the review of traditional revenue models to make way for new approaches to revenue generation. In conclusion, some future scenarios for both leisure and corporate travel distribution are outlined.
\end{abstract}

JEL L84

\section{INTRODUCTION}

The worldwide tourism distribution system is experiencing major transformation. The beginning of this transformation phase can probably be traced to the deregulation of airlines and the advent of global distribution systems, which initiated a period of greater accessibility and availability of information to travel intermediaries, with concomitant benefits to the travel consumer. The decrease in fares, and pressure from airlines for decreased distribution costs have made travel intermediaries vulnerable in terms of their traditional role as the link between supplier and consumer. Rapid and fundamental changes in technology have enabled consumers to deal directly with travel suppliers in an increasingly simple way, and this has proved a further impetus for change in travel distribution. Together with these trends, consumer preferences have also changed fundamentally. Travellers today seek different types of experiences from their predecessors and this, together with greater accessibility and availability of information, presents the travel industry with its greatest challenges.

This article gives an overview of these agents of change and of how the travel distributor and intermediary are coping with them. The article begins with a 
review of the traditional chain of distribution and then examines the trends and factors that are bringing about the changes to this traditional approach. Then it examines the reaction of travel intermediaries to these changes, and the survival strategies that they are implementing. The paper concludes with a possible future scenario for tourism distribution.

\section{THE TRAVEL DISTRIBUTION STRUCTURE IN SOUTH AFRICA}

A traditional travel distribution system links the suppliers of travel products to the end customers. This system can be described as a predominantly linear chain of distribution, because it follows the traditional path from supplier to wholesaler and/or retailer and finally to consumer. The number of channel levels may vary from simple, direct marketing where the supplier sells directly to the consumer, called direct distribution, to complex distribution systems involving several layers of channel members such as retail travel agents, tour wholesalers/operators and speciality intermediaries, called indirect distribution. The basic structure of the South African travel industry is graphically illustrated in Figure 1. The public or consumers can be seen as the driving force - they purchase travel services from retail travel agents or directly from the suppliers of travel services. The tour wholesaler's role is that of consolidating the services of airlines and other carriers with the requisite ground services into one package that can be sold either through travel agents to the consuming public - or directly. The legal and regulatory environment in which the industry operates may be viewed from two perspectives: firstly, the role of the government and other public bodies, and secondly, the role of industry associations such as IATA (International Air Transport Association) and ASATA (Association of Southern African Travel Agents). 
Figure 1 The basic structure of the South African travel industry

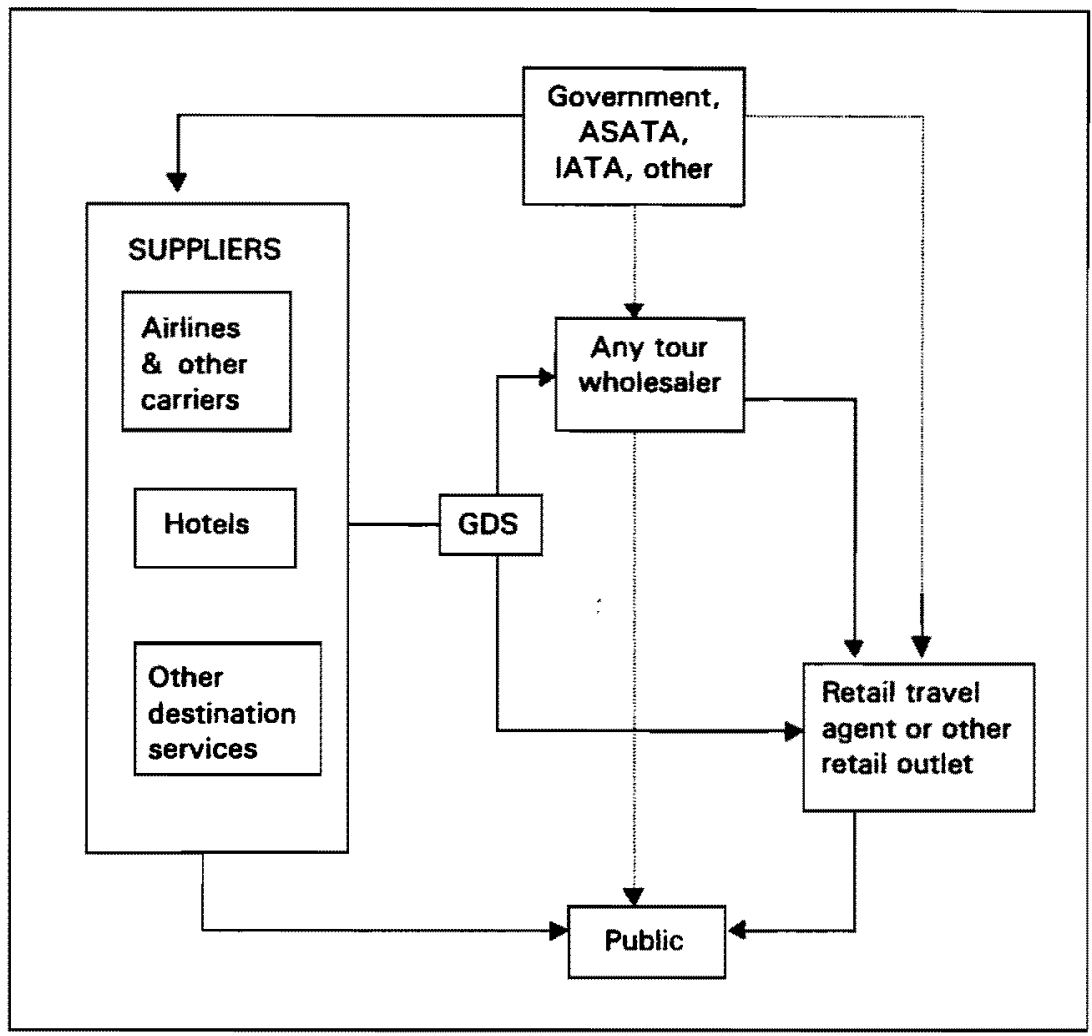

The role of the travel suppliers is to provide travel and transport related services to consumers. Because of the intangibility of the tourism product, they rely on the distribution of information. The information is stored in global distribution systems (GDSs) such as Amadeus, Galileo, Sabre and Worldspan, and disseminated to the consumer via the travel intermediaries, who are linked to these GDSs. The last-mentioned have traditionally been the main tool used by the travel industry to distribute information about air travel and other products, such as package holidays, hotel accommodation and car hire.

Travel intermediaries may be divided into wholesalers and retailers. The tour wholesaler buys different components of the tourism product, like transportation, accommodation and sightseeing, from suppliers to create packages that are sold via the travel agent to the consumer. The travel agent has traditionally been the dominant sales channel for airline and tour operating 
companies. For many years, airlines have been dependent on travel agents to sell their seats, with approximately $80 \%$ of all sales being done through travel agents. This holds true even today, despite the growth in direct distribution through the Internet.

In 1998 there were approximately 71 international scheduled and non-scheduled airlines servicing South Africa. Before 1990, only 22 international carriers did so, which means that there has been a rapid increase in the number of new destinations accessible to the South African traveller. Thus between 1990 and 1998, travel agents and tour wholesalers had to increase their range of products rapidly, and expand their information systems to meet the new demand. According to IATA, international airline ticket sales in South Africa through travel agents amounted to approximately R4 billion in 1996, while domestic airline ticket sales were approximately R2 billion in that year. In 1998, total airline sales through travel agents amounted to R8,45 billion. The number of domestic and regional airlines in South Africa has also increased during the last few years. South African Airways (SAA) remains the largest carrier, with other airlines, like British Airways/Comair, SA Express, Nationwide Air and SA Airlink, also serving the regional and domestic routes. Apart from government licensing, airlines are regulated by IATA.

The retail travel industry consists of licensed as well as unlicensed travel agents. In 1998 there were approximately 1000 travel agencies in South Africa, of which 820 were licensed by IATA. These agencies range from independent neighbourhood and small-town travel agencies to large organisations (e.g. Rennies Travel) that are part of JSE-listed holding companies, like Bidvest. Travel agencies may also be part of a national franchise like Sure Travel, which has over 125 independent city outlets, or international franchises, like Harvey World Travel. A number of airlines have provided franchising opportunities for travel agencies (e.g. SAA City Centre travel agencies), and alliances are also formed between local travel agencies and global partners. Examples are the affiliations between Concorde Travel and the global giant Carlson Wagonlit, and Rennies Travel and BTI (Business Travel International). While travel agencies require IATA licences to issue air tickets, ASATA is the industry association that represents the travel trade. The growth in the travel agency market, and the importance of travel agents in South Africa, are evident from the increase in the total number of airline sales processed through travel agencies: R3,6 billion in 1993 to $\mathrm{R} 8,45$ billion in 1998 .

The rapid rise in the number of destinations available to the South African traveller since 1995, has compelled the travel trade to become quickly familiar with more countries than it ever had to deal with in the past. According to Satour 
(Bayman, 1998), outbound overseas travellers in 1996 amounted to 549379 persons, of whom 416041 were holidaymakers, 123043 business travellers and 10295 academics and others travelling for study purposes. In 1997 a total of 518514 South Africans travelled overseas; 387408 (a drop of almost $7 \%$ from 1996) travelled on holiday, 120890 on business (a drop of $1,75 \%$ ) and 10216 travelled for study purposes (a drop of $0,77 \%$ ). At present there are approximately 22 ASATA-registered outbound tour wholesalers in South Africa, some of the larger being World Leisure Holidays, ATO, Thompsons Tours, Beachcomber Tours, Absolute Tours and Travel Vision. The South African Tour Operators Association (Satoa) represents the outbound tour sector of the industry.

The inbound tourism sector has grown substantially since 1994, and according to Caras (1998: $47-8$ ) there are approximately 460 operators providing ground tours in South Africa, about 15 of whom may be considered major players in the sector. A Satour survey (Caras, 1998: 48) shows that $27 \%$ of the foreign visitors to South Africa, over 300000 tourists a year, participated in organised tours - a significant increase from the $17 \%$ in 1995 . Inbound tour operators handled about 220000 tourists in 1995. Two industry organisations, namely Satsa (the South African Tourism Services Association) and Asinto (the Association of Inbound Tour Operators), which is part of ASATA, represent the interests of the inbound tour market.

Apart from the changes in South Africa's circumstances over the last number of years, changes in the overall tourism industry have and are occurring so rapidly that it is necessary to examine how distribution in travel is being impacted and how transformation in the industry is taking place.

\section{CHANGES IMPACTING ON TRAVEL DISTRIBUTION}

Changes in three important areas can be identified as having the greatest impact on the way in which travel is distributed. These are:

- deregulation in the airline industry

- rapid advances in technology

- changes in consumer demand and behaviour

They are next discussed in turn. 


\section{Deregulation}

Since 1978, when deregulation of the airline industry was introduced in the USA, competition in this and related travel industries has burgeoned. This increase in competition caused declining yields for many travel suppliers and a subsequent squeeze on revenues, and ways were therefore sought to reduce costs and increase market share and profitability. As far as airlines are concerned, deregulation and increased competition brought about a number of changes, which directly impact on travel distribution. These are:

The formation of alliances. The alliance trend amongst airlines began in the mid-1980s. The main aim with alliances is to extend the market reach of airlines, control costs and possibly limit competition in the global air transport sector. While some concern has been expressed as to how alliances affect the consumer, it can be argued that they have vastly extended passenger choice. These alliances include collaborative pacts ranging from equity stakes to codesharing agreements, joint services, block seat or block booking arrangements, joint marketing agreements, joint fares and franchise agreements (French, 1997). Not only does South African Airways form part of a strategic alliance (the Star Alliance) together with Lufthansa, United Airlines, Air Canada, SAS and Thai Airways International, it also has various code-share agreements with other carriers such as Singapore Airlines. SAA has also found an equity partner in Swissair. Another South African airline, Comair, has a franchising agreement with British Airways, the latter having bought a $18,3 \%$ share in Comair. These alliances bring about changes in ticket distribution methods that directly affect the retail travel industry in terms of preferred supplier relationships and revenue. Franchising travel retailers as preferred suppliers of certain airlines are also very much in evidence in South Africa, as the rapid growth of the SAA/Lufthansa City Centre travel centres has shown.

A strong move to cut distribution costs. As the level of competition increases airlines continue to look for ways to offset declining profits. This has resulted in a move to reduce distribution costs, which represent $20-25 \%$ of total costs. This move by airlines has resulted in the implementation of commission caps in the USA. Commission cutting has started in South Africa, with SAA cutting commission on international ticket sales from $9 \%$ to $7 \%$ and other airlines following suit. Commission capping and other changes in commission structures have severely affected the major source of travel agents' revenue, and will continue to do so.

Introduction of more competitive and flexible fares. This has meant a decrease in the cost of air travel to the consumer. New airlines increasingly enter the market and compete with national carriers, traditionally protected by government 
subsidies and regulation. The flexibility of fares on the Johannesburg/London route offered by British Airways, SAA and Virgin Atlantic is an example of the wider range of options available to the consumer.

Introduction of airline loyalty programmes. A factor that should not be underestimated in its impact on travel distribution, is the implementation and growth of the so-called frequent flyer programmes. These are designed to create brand loyalty among passengers, and according to Lewis and Talalayevsky (1997) tend to reduce the use of travel agents. The frequent flyer passenger will be inclined to deal as much as possible with a single airline (or airlines operating within the same alliance, where frequent flyer points are transferable) for future redemption of points. Frequent flyers will be tempted to deal with the airline directly, having decided beforehand on a carrier. Airlines have more information on frequent flyers than other passengers, because it supports their marketing and scheduling decisions, and they will want to make optimal use of such information. This leads to strategies where the travel intermediary may be bypassed in order for airlines to strengthen their relations with frequent flyers.

These trends in the airline industry have had a major negative impact on the revenues of travel intermediaries, particularly of the travel agent.

\section{Rapid advances in technology}

The travel industry has used information technology for more than twenty years. This technology has become indispensable in lowering the cost of business processes such as reservations, accounting and administration, as well as improving customer service, human resource and financial management. While information technology is a key competitive weapon in the travel industry, it also holds the biggest potential threat to the way that travel agencies operate and even to their very existence. As travellers begin to make more of their own reservations electronically, thus bypassing the travel agent, the role of the travel agent will change towards a greater emphasis on advice and planning.

Information technology is making a significant impact on all organisations. In the past five years, direct electronic communication with consumers has become possible through the Internet, online services, and the use of telephones to communicate directly with computers. According to Lewis and Talalayevsky (1997), it is no longer in doubt that it will be possible to bypass intermediaries, who are no longer necessary for the coordination and management of information. 


\section{The Internet}

The relatively low barriers to entry, the perception of a demographically attractive and expanding international user base, and growing media attention, have prompted a sharp rise in the number of Internet sites with a travel and tourism focus. Using the Internet removes the limitations of time, place and products. As more people become computer literate and familiar with the Internet, travellers will increasingly start to make their own bookings for flights, hotels and car rentals. The Internet provides a means of reducing costs by removing intermediaries from the distribution chain and allowing consumers to deal directly with travel suppliers. Olivier (1996) calls the bypassing of the travel agent disintermediation. The Internet is one of the prime forces that could bring about such disintermediation.

The cost to suppliers of receiving a customer's booking is the most compelling issue here. According to Inkpen (1998) it has, for example, been estimated that the cost of making a booking via a telephone service centre is around US\$10, and via a GDS around US\$3.50. To secure that same booking via the Internet costs only 25 cents. Intermediaries represent a substantial element of supplier distribution costs. As their role declines, profit margins along the value chain will be redistributed to producers and consumers. It has been estimated that over 100 million people would be on the Internet by the turn of the century (Olivier, 1996). The travel industry is not exempt from this trend, with increasingly more hotels, airlines, tourist offices, et cetera, establishing themselves on the Internet, which has also been used to auction 'late availability' airline seats. For example, South African Airways held its first auction on the Internet in April 1997. Here ten seats were auctioned on local commercial flights, with the Johannesburg/Durban seats going from R130 (as opposed to a normal single fare of approximately $\mathrm{RSO0}$ ) and the Johannesburg/Cape Town seats going for around R260 (as opposed to a normal single fare of approximately R900).

\section{Electronic ticketing}

Some airlines offer travellers the option of booking flights without tickets. The traveller obtains a boarding pass at the airport on confirmation of his or her identity. Inkpen (1998: 71) describes e-ticketing as a CRS supported function that can be used to book the following:

- Airline seats sold directly to customers by the carriers themselves. British Airways/Comair has a system whereby passengers prebook their flight, pay by credit card and go directly to the check-in desk at the airport, where they are issued with a boarding pass on swiping their credit card and showing their acknowledgement, already faxed through to them. British Airways has a machine at Heathrow Airport that accepts standard credit cards for self-booking flights. 
- Airline seats sold to customers via the travel agents. Travel agents have access to e-ticketing functions via their GDSs, which are connected to the airline's CRS. So, for e-ticketing to be possible from a technical standpoint, the airline's CRS and the travel agent's GDS must both support e-ticketing functions. Some reservations systems are introducing "electronic ticketing" into South Africa, which would enable travel agents to issue electronic tickets.

\section{Intranets}

Intranets are systems developed from the Intemet, mostly private networks owned by companies. These tailor-made networks can be accessed only by company employees using a special password. The Intranet allows company staff to make their own travel arrangements direct from their laptop computers anywhere in the world. These systems are expected to be available in South Africa from the year 2000 .

\section{Self-service kiosks}

These are intelligent ATM-type machines activated by customers. They have a link to suppliers' electronic distribution systems and provide direct access to the consumer.

\section{Smart card technology}

Smart cards look like credit cards, but have a computer chip embedded in the card that can store, read and dispense large quantities of information on command. People have come to expect a "travelling office" (Cole, 1996) that will give them connectivity and technical support at every stage of their joumey.

\section{Telephone voice recognition}

This is a system where computers "speak", which can be used by airlines and other suppliers to answer enquiries about reservations, lost baggage, schedules, et cetera.

\section{Telephone conferencing}

South African companies are increasingly using telephone conferencing and international phone cards as cost-efficient ways of communication, and an alternative to international travel.

\section{Paradigm shift}

Webb (1997) suggests that technology is making it easier for travel distribution channels to come under the control of powerful industries, for example, retail grocery chains. Retail groups like Pick 'n Pay and Computicket have the critical mass and technology to move into simple travel transactions. This is also seen in 
acquisition of related companies or alliances with such firms (e.g. Rennies Travel).

These pressures on the travel industry require a restructuring to meet the demands of the future, that will be a challenge to their managers.

\section{Changes in consumer demands and behaviour}

Changes in consumer behaviour, expectations and values represent another of the main forces behind the pace and direction of industry developments (Andersen Consulting, 1998). In the leisure market, consumers are becoming less satisfied with traditional holiday packages. "Mass tourism" has been replaced by the so-called "new tourism", which is strongly emerging in South Africa too. Mass tourism was the logical outcome of the key social, economic, political and technological influences following World War II. This form of tourism began with the introduction of jet aircraft in 1958. Post-war peace and prosperity, paid holidays, charter flights and cheap oil resulted in massive changes in the tourism industry. Sun-worship, inexperienced tourists, the availability of cheap package tours to attractive destinations and "plastic cards" all boosted the demand for mass tourism. This is also called Mass Standardised Rigidly Packaged (MSRP) tourism, because identical holidays were rigidly standardised and mass-produced. The holidays were consumed en masse by a seemingly identical group of mass travellers, with no consideration for the environment, or the values and culture of the host society. Technology greatly facilitated the development of mass tourism because it made possible the standardisation, management and distribution of mass tourism services on a global scale. By the 1970 s and 1980s, mass tourism had become "best practice".

New tourism, which is in the process of emerging in South Africa, is fundamentally different from mass tourism. New tourists are more experienced, more "green", more independent, more flexible, more quality conscious and harder to please than mass tourists. The previous generation of tourists wanted only to go to a place and be able to prove they had been there, whereas new tourists go on holiday to experience something different. Quality and value for money are vital to them and they are spontaneous, unpredictable and hybrid in their choice of holidays. They want to affirm their individuality and to be in control. As familiarity with new technologies increases, the consumer experiences an added element of control and convenience of how travel services are bought. The industry is therefore seeing a shift from the traditional push of products by travel suppliers to the pull of products by consumers, based on the growing availability of transparent, easy-to-use technology (Andersen Consulting, 1998). 
In response to these destabilising trends, travel intermediaries have reacted and developed in three important ways. The first is the consolidation of travel companies through mergers, acquisitions, franchising and the formation of consortiums. The second is through their increased use of technology to benefit both client and travel company. A third fundamental change that is taking place in the way travel intermediaries do business, is the restructuring of their revenue base, where a strong move is emerging away from the traditional revenue model of commissions to a more flexible, service-fee model.

\section{TRAVEL INDUSTRY RESPONSES TO CHANGES}

\section{Consolidation and integration of travel companies}

The increasing number of consolidations in the travel industry comes from the growing recognition of the benefits of co-ordination of travel services in response to the challenges facing the industry. Travel intermediaries have shown more and more appreciation of the difficulties they face in achieving the benefits from the traditional chain of distribution and their position along this chain. Integration in the form of acquisitions, alliances, mergers, franchises and consortiums has followed a rapid path in the travel industry, both worldwide and in South Africa. Integration achieves three basic benefits for organisations:

- Competitive advantage through speed and flexibility. Through integration of sophisticated technology, rationalisation is possible, and with a wider product range to offer the organisation's image is enhanced.

- Cost control through efficiency and rationalisation. Organisations achieve greater negotiating power with suppliers, save on fixed costs, gain access to broader industry experience and have greater access to technology.

- Extending market reach through access to wider markets.

The five above-mentioned forms of integration are next discussed in turn.

Acquisitions: A good example of integration in the tourism industry is that of the Tourism Investment Corporation Ltd (Tourvest Ltd), a company listed on the Johannesburg Stock Exchange. The vision of Tourvest is to be one of the top 10 global tourism companies, and it has already acquired numerous companies in the inbound and outbound tourism markets as well as related sectors. Tourvest believes that the benefits that accrue from its acquisitions are:

- buying power

- cross-selling within the group

- sharing skills and expertise, thereby creating a Tourvest culture

- uniform budget and business planning tools 
- central support providing strategic input and management support

- integrated electronic product

- implementation of a comprehensive database

Alliances: Alliances are a form of contractual agreement that allows two organisations to benefit from each other's strengths (Kotler, Bowen \& Makens, 1996). Local travel agencies are increasingly forming alliances with global travel management organisations through which they gain access to international systems. Examples of alliances formed in South Africa are Concorde Travel and Carlson Wagonlit, which has 4000 outlets in 125 countries, and Rennies Travel and BTI, which has 2750 outlets worldwide. These types of alliance provide the consumer with more choices and a greater degree of security while travelling. This puts pressure on the small independent travel agency, which does not have the same purchasing power and credibility overseas.

Mergers: A merger can be defined as the combining of two or more entities through direct acquisition by one of the net assets of the other, either friendly or hostile, for cash or stock. A new corporate entity is not created, but a newlymerged organisation resembles a new organisation due to changes that follow the merger. A recent example (1998) of a merger in South Africa is that between Beachcomber Tours, one of the largest tour wholesalers in South Africa, and Creative Tours. Beachcomber Tours is a leading wholesaler of holidays to Mauritius, and to expand on the Mauritius side of the business it bought Creative Tours after splitting Beachcomber into two companies. The first company remains Beachcomber Tours with its primary focus still on Mauritius, and the second company, called Absolute Tours (and incorporating Creative Tours) now focuses on the UK, the continent of Europe, Australia and South Africa.

Franchising: Traditionally the travel agency business has not been suitable for franchising. It has always been a relatively low-revenue producing, low-income business not able to support franchise fees, yearly service fees and other such expenses. However, in a business environment that is becoming less and less regulated, the travel agency industry is likely to experience a growth of nationwide and even worldwide chains. Independent agencies are increasingly feeling the need to enjoy the benefits of strong advertising and a corporate image.

Internationally, franchising began in the travel industry in the early 1980s. Uniglobe in Canada exemplifies this rapidly expanding business form. It was founded in 1980, has currently 850 units operating in North America and has now started operating in South Africa too. Operation was launched in the United Kingdom in 1990 and has rapidly expanded to 70 outlets. The core business is the corporate travel agency market. In South Africa some of the more wellknown franchises are the SAAVity Centre franchises, Sure Travel and 
Concorde Travel. South African Airways, as an alliance partner of Lufthansa, launched its SAA/City Centre travel agency franchising concept early in 1997. The rapid growth since 1995 of the Sure Travel franchise, which has over 125 franchise outlets in South Africa, indicates the growing need for travel agencies to link together to form strong management structures. Smaller independent agencies increasingly feel isolated and disadvantaged in terms of buying power and access to global services, hence the rapid growth of franchising.

Consortiums: Consortiums also provide small independent agencies with the opportunity of increasing their buying and marketing power. For example, the Independent Travel Agents Consortium (Itac) was launched in 1997 with a membership of 49 travel agencies and a combined buying power between R500 and R600 million, with the aim of negotiating better deals for its members with product suppliers (Birns, 1997). Although consortiums may be similar to franchising in terms of payment of membership and monthly fees and their aim of increasing individual members' buying power, a key difference is that they normally allow members to retain their own corporate identity and management independence.

An interesting example of the combination of alliances, joint ventures and franchising that can take place is provided by Rennies Travel. As already mentioned, Rennies Travel have formed an alliance with BTI. In 1997 they also signed a 50-50 joint venture agreement with an Australasian company called Harvey World Travel to develop a leisure-based travel franchise in South Africa. They have also linked up with Computicket, the leisure retail company, to allow Computicket to make foreign exchange transactions for foreigners (Getz, 1997).

According to Cole (1996) the future operation of the large, global companies will be quite different from that today as a result of the consolidation of travel agencies. For example, travel agents will become more specialised, with a vast fund of data and experience to draw on for the traveller contemplating, say, a safari or a scuba-diving expedition. Greater specialisation and a fuller range of products also open the way to a fee-based revenue model.

\section{The use of technology by travel intermediaries}

Travel agents and other travel intermediaries have traditionally used information technology mainly for information retrieval and reservations, electronic ticketing and computerised back-office systems. GDS terminals are the major information and booking tools used by travel agents for all types of travel products. The major systems available to travel agents are Sabre, Apollo/Galileo, Worldspan, Systemone, Amadeus and Abacus. In South Africa Galileo is used by 90 percent of agents with Amadeus making steady inroads. 
These GDSs are constantly providing extra tools to increase the travel agency's efficiency. Windows interfaces have been developed that allow agents to move between applications. Travel agents are also using technology such as CD-ROM to enhance their selling of destinations. CDs are used as an alternative to brochures. The installation of CD-ROM applications, whereby descriptions of destinations can be done via colour photographs, sound and video clips, has become necessary as increasing amounts of information are distributed. Another way in which agents have improved their service, is by setting up satellites in the offices of their bigger corporate clients, thus allowing immediate discussions, advice and instant ticket issue to take place.

While travel agencies are under threat from the Internet, it also provides additional business opportunities. An ever-increasing number of travel agents in South Africa are gaining access to the Internet through their GDS. Some travel agencies offer services on the World Wide Web, giving them a much broader geographic consumer base than they could acquire by traditional methods. Travel agencies on the Internet can receive bookings from clients through the Internet and can either send tickets by post, by hand or electronically, or can book the passenger on ticketless flights. Communication with suppliers can also be done via e-mail. There are a number of electronic travel agencies on the Web, such as Expedia, BIZTRAVEL.COM and THE TRIP.COM. Internationally, the travel industry has been active and aggressive in deploying consumer-oriented eCommerce applications focused on the distribution aspects of travel services. As a result most of the leading travel providers, GDSs and travel agents have now established sites enabling consumers to obtain information and, in many cases, book and pay for tickets via the Internet (Andersen Consulting, 1998). In South Africa the leading company in the sphere of Web-based travel is eTravel, closely pursued by Leisure Travel and Computravel.

\section{A new agency revenue model}

Historically, travel agencies have eamed their revenue through commission paid to them by suppliers such as airlines, hotels, car rental companies and other service providers. This revenue was sufficient to cover the agencies' fixed and variable costs. However, traditional commission rates are giving way to fees based on value-added services (paid by the traveller). This will transform the travel agent into an agent for the traveller rather than for the travel provider. The shift away from commission-based revenue to fees, is becoming increasingly important with distinction being made between fees charged for handling corporate accounts and fees relevant to individual travellers. Dr Robert Joselyn, President and CEO of Joselyn, Tepper \& Associates, Inc. in Arizona, suggests that fees should be charged for the following services : 
- Those which do not generate income commensurate with cost of service or investment in service.

- Those where the agency is capable of adding value.

- Those where customers view fees and service charges as fair and reasonable.

Where the small business account and leisure traveller are concerned, and with constant emphasis on the right kind of service, Joselyn proposes fees such as:

- Penalty charges that are designed to recover costs and/or to compensate for lost income from efforts which have already incurred cost, or to compensate for costs incurred for redoing work already done.

- Service fees for performing services (generally a combination of time and transaction expertise/capability) for which no income or inadequate income is anticipated.

- Professional fees for experience and expertise that are either not compensated, or inadequately compensated.

The fee structure for corporate accounts should be negotiated with corporate clients on a contractual basis. Revenue from corporate accounts can range from commission to the agent (with commissions and overrides from preferred suppliers going to the agent only), a fixed management fee structure or profit sharing between the corporate account and the agent. Other agreements or variations of these types of fees can also be negotiated based on the types of service required.

\section{A FUTURE SCENARIO FOR TRAVEL DISTRIBUTION}

Rapid technological advance has brought about new electronic distribution channels like the Internet, personal digital assistants, self-service kiosks and interactive television, which have enabled the consumer to reach the supplier directly and, in so doing, to bypass traditional distribution organisations like the travel agent. These electronically based channels have also provided the consumer with a greater choice of products. The use of these new channels depends on consumers' technological know-how and traveller sophistication.

Andersen Consulting (1998) suggests that in future, these new channels will run parallel to the traditional channels of distribution, with customers selecting the channels according to the complexity of the travel experience and its occasion or purpose. The retail travel agency as we know it today, will all but disappear in the transformed corporate travel distribution system. According to Andersen 
Consulting (1998) there will be a move towards self-booking where the individual business traveller makes direct contact with the GDS or the supplier inventory system, particularly if travel arrangements are relatively simple. This will be done through corporate Intranets accessible via personal computers, personal digital assistants or telephones using voice recognition systems. Journeys and itineraries that are more complex will still require the services of a travel consultant. The travel consultant will no longer be an "order-taker" but an adviser and consultant in the true sense of the word, providing information and advice and adding value to the travel transaction. For corporate travel, where large travel accounts are handled, global travel management companies will emerge to replace the traditional retail travel agency. These companies will serve the needs of their clients by managing their travel portfolios. Traditional sources of revenue, such as commissions, will no longer apply and global travel companies will work on a basis of client fees. The model for leisure travel will be more complex, with traveller sophistication, technological know-how and buyer values determining the future "look" of distribution. Similar to the corporate market, the traveller with a relatively simple itinerary will tend to bypass the retail travel agent and book directly with the supplier through personal computers, television and self-service kiosks. When travel is more complex, Andersen Consulting (1998) suggests that distribution will be split along direct and traditional channels. Travel that was previously regarded as complex will become increasingly simple, as packages are developed that reduce the complexity of travel. Consumers are increasingly able to access information previously regarded as complex but now becoming relatively simple to access online. However, leisure travellers will continue to rely on retail travel agents offering value-added services to assist in planning more complex, adventurous itineraries. In such cases, travellers will still choose to visit a retail travel agent's shop to obtain advice in a face-to-face context.

\section{SUMMARY}

This article looked at the trends that are emerging in the travel industry, with particular reference to travel agencies. It is evident that the industry is currently experiencing probably its greatest changes and challenges since the $1960 \mathrm{~s}$. Travel agencies began as independent organisations serving a relatively simple market, but greater specialisation in types of travel, more discerning travellers, the deregulation of airlines and tremendous technological advances have resulted in the growth of complex alliances, partnerships and franchises. Not only are these trends posing a threat to the small independent travel agency, they are also fundamentally changing the traditional chain of distribution. The distribution system will look different in the future, with multiple channels nunning parallel to one another and serving different market segments. 


\section{REFERENCES}

1 ANDERSEN CONSULTING (1998) The Future of Travel Distribution, Research report, Johannesburg. Andersen Consulting.

2 BAYMAN, F. (1998) "Report Overstated Drop in Travellers", Travel News Weekly, 1554: 5.

3 BIRNS, H. (1997) "Itac Launched with 49 Members", Travel News Weekly, 1494: 24.

4 CARAS (1998) Tourism Talk: A Bulletin on Tourism and Its Allied Industries, Johannesburg: Kessel Feinstein Consulting.

5 COLE, J. (1996) "The impact of Information Technology on Travel and Transportation", A Public Affairs Paper from IBM, Asata Technology Workshop, Johannesburg.

6 FRENCH, T. (1997) "Global Trends in Airline Alliances", Travel \& Tourism Analysis, 4: 81-101.

7 GETZ, M. (1997) "Rennies Signs Accord with Australasian Firm", Pretoria News Business Report, 8 October: 3.

8 NKPEN, G. (1998) Information Technology for Travel and Tourism, Essex: Longman.

9 KOTLER, P, BOWEN, J and MAKENS, J. (1996) Marketing for Hospitality and Tourism, Upper Saddle River: Prentice-Hall.

10 LEWIS, I and TALALAYEVSKY, A. (1997) "Travel Agents: Threatened Intermediaries" Transportation Joumal, 36(3): 26-30.

11 OLIVIER, APS. (1996) "The Revolutionary Impact of the Internet on the Travel Agent: Friend or Enemy?" Paper presented at the IRIS 1996 Conference on The Future, 10 - 13 August, Göteberg.

12 WEBB, G. (1997) "Pick 'n Pay Penetrates Retail Market", Travel News Weekly, 1463: 2. 